\title{
The Sino-Russian relationship in the mirror of the Cold War
}

\author{
Sergey Radchenko ${ }^{1}$
}

Received: 19 September 2019 / Accepted: 23 December 2019 / Published online: 16 January 2020

(c) The Author(s) 2020

\begin{abstract}
This article uses a constructivist lens to discuss the history of the relationship between Beijing and Moscow from 1949 to the present. It argues that the dramatic shifts in this relationship can be understood in reference to mutual perceptions of China and Russia by their political elites in the broader context of a global hierarchy dominated by the United States.
\end{abstract}

Keywords Sino-Soviet relations $\cdot$ Mao Zedong $\cdot$ Nikita Khrushchev $\cdot$ Cold War

\section{Introduction}

Frequent meetings between world leaders are nothing astonishing in our rapidly changing world. But even by contemporary standards Chinese President Xi Jinping and his Russian counterpart Vladimir Putin are seeing a lot of each other. They have met at least 30 times since Xi assumed power in China in 2013. They have developed a close working and personal relationship. Xi Jinping recently called Putin his "closest friend", while the Russian President highlighted the "unprecedentedly high level" of Sino-Russian cooperation. ${ }^{1}$ The Sino-Russian relationship has always been-and remains today-deeply personalized, and such positive assessments by the two leaders matter a great deal. Assessments such as these shape internal and external perceptions of the relationship. To paraphrase Alexander Wendt, Sino-Russian relations are very much what $\mathrm{Xi}$ and Putin make of them (Wendt 1992). This is not to say that no one else matters. Leaders do not exist in vacuum, and the views they hold are often in and of themselves merely a personalized reformulation of prevalent narratives. It is fair to say that leaders shape the narratives and are, in turn, shaped by them.

Understanding the Sino-Russian relationship through the constructivist lens is helpful in explaining change. Beijing and Moscow have been on a rollercoaster ride

\footnotetext{
1 Press statements following Russian-Chinese talks. Kremlin.ru. June 5, 2019. https://kremlin.ru/events/ president/news/60672. Accessed 20 Dec 2019.
}

Sergey Radchenko

radchenkos@ cardiff.ac.uk

1 Law School Building, Cardiff University, Cardiff CF10 3AT, UK 
since establishing diplomatic relations in October 1949. The first decade was one of eternal and unbreakable friendship that turned out to be neither eternal nor as unbreakable as propaganda claimed. The 1960s were a decade of great polemics: China and the Soviet Union accused each other of betraying Marxism-Leninism and selling out the revolution. In the following years, ideology played a decisively lesser role in the relationship, which now resembled a more traditional confrontation between two great powers. Students of Sino-Soviet relations began attributing the enduring conflict to the clash of national interests between Beijing and Moscow. Yet, the confrontational dynamic began to change in the 1980s; by 1989, China and the USSR normalized their relationship, which has since then improved by leaps and bounds to the point of a de facto alliance.

Such remarkable amplitude of movement-from alliance, to the brink of a nuclear war, to something that once again resembles an alliance-raises important questions about the underlying determinants of Sino-Russian relations. For if so-called "national interests" determine the relationship, why is it that these national interests allow for such dramatic variations? Clearly, the issue is not so much the interests but perceptions of these interests. Perceptions are subject to rapid change, because they are context dependent. It is impossible to understand how the Chinese and the Russian leaders perceive their relationship without taking into full account their views on China's and Russia's places in the world, and how these two countries relate to the United States, the collective "West", and the Global South. It is the variation of these perceptions that accounts for such dramatic swings in the Sino-Russian relationship.

This brief commentary reviews the evolution of ties between Beijing and Moscow since 1949. It must be remembered, of course, that the history of bilateral interactions is much longer than that-it extends all the way back to the seventeenth century - a rich luggage that also has indelible impact on present-day perceptions. Nevertheless, 1949 is a useful starting point, because it marked the emergence of the Chinese Communist Party (CCP) on the global stage. Its leaders, first and foremost Chairman Mao Zedong, had peculiar ideas about where China would fit in the global world order, which was at that time shaped by the unfolding Cold War. These ideas were tested against political realities as Mao embraced the Soviet dictator Joseph Stalin. How did Mao and Stalin see each other, and their countries' positions in the global hierarchy, and how did these perceptions change after Stalin's death? How did Mao relate to Stalin's successors, Nikita Khrushchev and Leonid Brezhnev, and how did Mao's death in 1976 in turn affect the relationship that had been so deeply shaped by his hopes and delusions? What accounts for the Sino-Soviet normalization of the late 1980s, and how long is the current episode of eternal and unbreakable friendship likely to last? Below, I address these questions in turn.

\section{The Sino-Soviet alliance}

On July 1, 1949, in a Renmin Ribao editorial, Mao Zedong famously proclaimed that Communist China would henceforth lean to one side-the Soviet side. The CCP had by then practically won the civil war. Mao's rival, Chiang Kai-shek had fled to Taiwan. The Chinese leader was now looking to position China in a world 
overshadowed by the political, economic, military, and ideological confrontation between the Soviet Union and the United States. In a sense, his choice-seeking alignment with the USSR - was a natural one. The CCP itself had been founded with Soviet involvement, and was ideologically affiliated with the world Communist movement, centered in Moscow. Mao had his share of disagreements with Stalin during the CCP's Yan' an decade (Mao would later complain of Stalin's lack of faith in the Chinese revolution), but these did not compromise the nature of the relationship: Mao still saw himself as the Soviet leader's subordinate in the global revolutionary hierarchy, and sought to emphasize this subordination both privately and publicly.

In January-February 1949, Mao had the opportunity to reiterate his understanding of the hierarchy to Stalin's envoy Anastas Mikoyan, when the two met at the village of Xibaipo. Mikoyan was in China in response to Mao's persistent requests for a meeting with Stalin (the Soviet leader rebuffed these approaches, probably, because he was still uncertain of the prospects for Communist victory). Mao wanted to reassure Stalin that he could be relied upon. This was especially important in light of the transgressions of Josip Broz Tito of Yugoslavia. In 1948, Yugoslavia was expelled from the Cominform, allegedly, because Tito refused to submit himself to Stalin's authority, and Moscow unleashed a virulent propaganda campaign denouncing the crimes of the Tito clique, reciprocated tit for tat in Belgrade. Mao knew that he would fall under suspicion as another potential Tito. He tried to prove that he was anything but. He repeatedly stressed that he was a "pupil of Stalin", that he held a "pro-Soviet orientation". 2

Mikoyan passed these helpful reassurances on to Stalin who, however, continued to have his doubts about the direction of the Sino-Soviet relationship. It was not that Stalin did not trust Mao (though of course he did not-nor, for this matter, did he trust anyone). For him, the question was broader. The Chinese Communists' triumph in the civil war was an entirely unexpected development, and it posed serious problems for Stalin's global strategy. This strategy was still largely tied to the agreements of 1945, that is - to the Yalta framework-whereby Stalin (so he thought) obtained tacit American recognition of post-war Soviet interests in Europe and Asia. It was in the context of the Yalta framework that Stalin reached a landmark agreement with (then still Chiang Kai-shek's) China-the August 1945 Treaty of Alliance. This treaty in all fairness was imperialistic and deeply unfavorable to China's interests. It forced Chiang to renounce claims to Outer Mongolia and grant Stalin important privileges in China, including a naval base at Port Arthur and a stake in the trans-Manchurian railroad. These were not just important gains, but they had been in effect ratified by the United States, which greatly increased their legitimacy.

Mao was now pressing to have the 1945 treaty replaced by a new treaty of alliance. He asked Stalin for a treaty during his landmark visit to Moscow from December 1949 to February 1950, but the Soviet leader appeared unwilling at first to allow

\footnotetext{
2 Memorandum of Conversation between Anastas Mikoyan and Mao Zedong. January 30, 1949. History and Public Policy Program Digital Archive, APRF [Arkhiv Prezidenta Rossiiskoi Federatsii, Moscow]): F. 39, Op. 1, D. 39, Ll. 1-6. Reprinted in Ledovskii et al. (2005), pp. 33-37.
} 
it. Stalin's reasons for keeping the old treaty are sufficiently clear: in addition to potentially undermining the Yalta framework, he could be inviting America's intervention in China, something he was eager to avoid. But what is far less clear-and this is a point that historians have endlessly debated-is why, after procrastinating for nearly two weeks - Stalin ultimately yielded to Mao's request, giving green light to the conclusion of the new treaty on February 14, 1950. The two most plausible arguments are tied, respectively, to China's agency, and to the Soviet intelligence capabilities. As to the former, Mao would later claim that his innocuous mention to Stalin's lieutenants that China may soon be recognized by Burma, India, and the UK, helped changed the Soviet dictator's mind. ${ }^{3}$ (In this reading, Stalin was afraid that he would lose China if he continued to drag his heels). As to the latter, historians have speculated that Stalin received advanced intelligence of the changing US defence posture, indicating that the Truman administration would pull support from Chiang Kai-shek (Heinzig 2015, 298).

Although Stalin ultimately agreed to sign a new treaty of alliance, he attached all kinds of unfavorable conditions, including some that seriously upset his Chinese guests. Thus, the Soviet leader managed to obtain Mao's agreement to a zone of exclusive Soviet interests in Manchuria, a quasi-imperialist privilege. He successfully insisted on the right (humiliating for China) to transport Soviet troops across Manchuria in wartime. The Soviets got to keep their naval base in Port Arthur (Lüshun), something that Mao did not only actually oppose, but also acquired stakes in several joint enterprises in China, which Mao definitely did not like. These were the so-called "bitter fruits" of the Sino-Soviet alliance, which the Chinese leader would repeatedly refer to in subsequent years, when the relationship was already crumbling.

But the reality for Mao was not all that bitter. China won Soviet security guarantees (a place under the "nuclear umbrella"). China also became the recipient of unprecedented economic aid from the Soviet Union. Whole industries (including military plants) were set up from scratch with Soviet help. Thousands of Soviet experts worked in China in the 1950s, and thousand more Chinese students journeyed to the Soviet Union and further afield to the socialist camp to study in every field of science. But most important of all, the Sino-Soviet alliance provided the Chinese leadership and Mao personally with a sense of global legitimacy. One could perhaps argue that the legitimacy was already there: the CCP drew its legitimacy from the Chinese revolution. That, however, would be only partially correct. The Chinese Communist revolution was closely connected to the global revolutionary narrative centered in Moscow. Stalin's blessing was important for Mao, for it confirmed that his revolution was not just some peasant rebellion but part and parcel of a global movement, rooted in "scientific" doctrines.

\footnotetext{
3 Memorandum of Conversation of Mao and USSR Ambassador to China N.V. Roshchin. January 01, 1950. History and Public Policy Program Digital Archive, Archive of Foreign Policy, Russian Federation (AVPRF), Moscow, F. 0100, Op. 43, D. 10, papka 302, 11. 1-4. Obtained by Odd Arne Westad and translated by Daniel Rozas. https://digitalarchive.wilsoncenter.org/document/110404. Accessed December 20, 2019.
} 
Mao demonstrated his loyalty to Stalin in 1950, when he took China to war against the United States in North Korea, even against better advice of some of his own Politburo comrades, who worried about the costs of war for the already impoverished Chinese economy. Of course, there were multiple reasons for China's ultimate involvement in the Korean War, not least security concerns, as well as Mao's efforts to improve domestic morale through foreign adventures (see, e.g., Hajimu 2015; Chen 2010). But there was also the boost in revolutionary legitimacy in fighting a war on Stalin's behalf - that is, in the brave exercise of revolutionary duty, no matter at what cost.

In his early discussion of relations within the socialist bloc, Mao used the term "family" (CPC Literature Research Centre 1989, 6). That family had a certain hierarchy in place. In that hierarchy, Stalin was a father-not a particularly generous one at that-and someone whom Mao later admitted he did not like. But whether or not he was likable, Stalin enjoyed the authority of a family patriarch, and the Chinese leader was willing to defer to him. But the grudging respect that Mao felt for Stalin did not survive the patriarch of Communism. When Stalin died in March 1953, the Sino-Soviet relationship entered a period of uncertainty. By 1958, the alliance was fracturing from within.

\section{The Sino-Soviet split}

Historians have disagreed over the reasons for the Sino-Soviet split, or its chronology. One school of thought holds that frictions began to develop in 1956 and stemmed directly from Nikita Khrushchev's denunciation of Stalin from the platform of the 20th Congress of the Soviet Communist Party (Wu 1999; Lüthi 2008). Khrushchev, who eventually succeeded Stalin at the helm, presently pronounced the late dictator guilty of unleashing unjust repressions and fostering a personality cult. Mao Zedong, whom Khrushchev did not consult before making these revelations, was unhappy: he felt that although Stalin did indeed commit mistakes (for example, his mistakes in relation to China), he was "a great Marxist-Leninist", and roundly condemning him was like "raising stone only to drop it on one's own feet". Added to this was a personal element: Mao, too, was a "Stalin" of a kind. He, too, had resorted to repressions against perceived counterrevolutionaries and enjoyed Stalinlike adoration in China. In a way, then, de-Stalinization in the USSR could be perceived as Khrushchev's attack on Mao.

Stalin was not just a man-he was a symbol. He stood for particular kind of domestic and foreign policies, including, for example, class struggle and the inevitability of conflict between capitalism and socialism. Khrushchev appeared to downplay class struggle and sought peaceful coexistence with the United States. Mao

\footnotetext{
${ }^{4}$ See, for example, Stiftung Archiv der Parteien und Massenorganisationen der DDR im Bundesarchiv [SAPMO-Barch] JIV 2/207 698, pp. 187-330 (in Russian). Obtained by Vladislav Zubok and translated by Benjamin Aldrich-Moodie. https://digitalarchive.wilsoncenter.org/document/111237. Accessed December 20, 2019.
} 
criticized these policies as "revisionist", setting the stage for the ideological conflict that fully unfolded in the 1960s. Historians who emphasize the ideological sources of the Sino-Soviet conflict usually point to 1956 as the turning point. The problem with the "ideological" approach, however, is that it artificially inflates the differences between the Soviets and the Chinese. For instance, the notion that Mao, unlike Khrushchev, underplayed the threat of a nuclear war and called for a more confrontational policy toward the West fails to acknowledge Khrushchev's brinksmanship from Berlin to Cuba. Khrushchev may have peddled peaceful coexistence, but it was on Mao's watch that Beijing proclaimed the five principles of peaceful coexistence as a guide for interaction with the non-Communist world, and then promoted these principles at the 1955 Bandung Conference.

Mao's light-hearted remarks about the A-bomb (in November 1957 he famously announced that a nuclear war would merely destroy capitalism and ultimately benefit socialism) worried the Soviet leaders who feared that the Chinese might drag them into a nuclear war. Yet, until 1964, China did not even have an A-bomb. Mao's controversial statements were often made simply for the sake of taking the high moral ground. In reality, the Chinese leader often acted with caution and circumspection, including, for instance, during the 1958 Taiwan Straits Crisis, when Mao carefully de-escalated hostilities with Taiwan, leaving Khrushchev puzzled over what the Chinese leader intended. In the mid-1960s, at the height of Sino-Soviet polemical exchanges, coinciding with the escalation of the Vietnam War, the Chinese leaders secretly sent signals to the United States in an attempt to set the limits for American involvement in the conflict (Hershberg and Chen 2006, 193).

Regardless of their ideological posturing, the Soviets and the Chinese had never acted strictly in accordance with the canon. Ideology was often used instrumentally by both Beijing and Moscow to legitimize and rationalize action taken for other reasons. It was also instrumental in the Sino-Soviet split, because it offered a rationalization for the seemingly inexplicable and unexpected deterioration of the supposedly "eternal" alliance. In a relationship defined by a strict hierarchy of the so-called international Communist movement, any fissures would of necessity have an ideological component, as otherwise how could one ever justify the breakdown of the hierarchy? ${ }^{5}$

The hierarchy began to break down in the mid-1950s, and it was de-Stalinization that set it in motion. It was, after all, Stalin who had imposed the hierarchy in the first place. His fall from the pedestal opened up opportunities for collective decision-making in the socialist camp, and Mao presently wanted his opinions to be taken into account. One could argue that he sought to seize leadership in the international Communist movement, but that would be too simplistic. Mao was a realist, and he understood that the Soviet Union was much better positioned to be the leader: it was an industrial superpower; it had the technological edge; it possessed nuclear weapons. China had great potential, but it could not yet compete on the same plane. Indeed, it was partly the result of the realization of China's present limitations that

\footnotetext{
5 For a study that highlights the Sino-Soviet struggle for leadership within the ideological hierarchy of the International Communist movement, see Shen and Xia (2015).
} 
in 1958 Mao launched the great leap forward that meant to propel the country to the ranks of a superpower (the Leap failed miserably).

Nevertheless, Stalin's death permitted Mao Zedong to raise his own profile as a global statesman, and he expected deference on Khrushchev's part. During the anti-Soviet unrest in Poland and Hungary, Mao was busy advising the Soviet leaders concerning the appropriate course of action (concessions in the Polish case and resolve in the case of Hungary). Even though Khrushchev's decisions not to intervene in Poland and to crack down in Hungary were taken for his own reasons (rather than Mao's counsel), the Chinese leader believed in the importance of his advice. In November 1957, during his second and final visit to Moscow, Mao proclaimed the Soviet Union to be the head of the socialist camp and called on all Communist parties to respect the Soviet leadership. But by thus backing the Soviets, the Chinese leader was implicitly placing himself in the position of a strategist-in-chief of the international Communist movement. As a seasoned revolutionary and self-proclaimed theorist of Marxist-Leninism, Mao believed himself to be infinitely more qualified than the post-Stalin leadership in Moscow to define the collective strategy for the bloc. But Khrushchev, increasingly secure at home and confident in his foreign policy moves, was unwilling to give Mao any real say.

A bizarre episode in 1958 illustrates the depth of Mao's bitterness about what he perceived as Soviet arrogance. The episode concerned the Soviet proposal to build a joint naval force, something Khrushchev had not thought particularly controversial given the intimacy of Sino-Soviet relations (indeed, the relationship had become so intimate that Khrushchev even agreed in 1957 to provide China with a prototype of an atomic bomb). Upon hearing of the new Soviet proposal (conveyed by Ambassador Pavel Yudin), Mao flew into rage. "You never trust the Chinese!" he declared in an oft-quoted conversation. "You only trust the Russians! [To you] the Russians are the first-class [people] whereas the Chinese are among the inferior who are dumb and careless" (Mao 1998, 322-333). ${ }^{6}$ Yudin was taken aback, alerted Khrushchev who then flew to Beijing to assure Mao that he never intended to build a joint navy, and that the ambassador simply misinterpreted his instructions. The episode is interesting because Mao's flare-up was of course not accidental: it was a calculated effort to signal resentment with what Mao perceived to have been Moscow's overbearing attitude toward a key ally. Perceptions are key once again: were the Soviets acting arrogantly, or where they being perceived as arrogant by overly sensitive audiences? There is no clear answer to this, since so much depends on the particular circumstances: the political, historical, and cultural contexts. It is here that the long and turbulent history of interaction between the two powers (including a period of outright Russian imperial encroachment) played an outsize role. Whether he wanted it or not, Khrushchev's every action was interpreted with reference to Russia's past imperial misdeeds.

A further variable in the equation of Sino-Soviet relations was the position of the United States, and its relationship with Beijing and Moscow. In the first PRC decade, the triangle was lop-sided. The US maintained a diplomatic relationship with Taiwan and helped enforce China's diplomatic and economic isolation. Intermittent

\footnotetext{
${ }^{6}$ Also available at: https://digitalarchive.wilsoncenter.org/document/116982. Accessed 20 Dec 2019.
} 
ambassadorial talks dragged on inconclusively in Warsaw, but bilateral interaction was minimal. Mao heartily embraced America's policy of non-recognition; not that he had any choice in the matter. "I don't think it bad that we are not recognized", he claimed in 1958. "Rather, it is a good thing, urging us to make more steel, say an output of 600 or 700 million tons, and then they will have to recognize us". He added: "At that point they could still feel free not to do so, but what difference would their nonrecognition make by then?" (Mao 1998, 268) Clearly, then, Mao valued recognition, which for him, like for Khrushchev, was linked to domestic legitimacy, but as a political realist, he fully understood that recognition would not be awarded for free; China had to prove itself worthy of recognition by achieving an economic breakthrough.

Khrushchev also craved American recognition. The United States and the Soviet Union maintained diplomatic relations, but the Soviet leader wanted something greater than that: America's acknowledgement of the Soviet Union as an equal. He also connected "greatness" to economic performance and set targets (many of which were missed) for overtaking the United States in the production of various goods and foodstuff. But the Soviet leader had a very special claim to superpower equality: a nuclear arsenal that, after the development of Intercontinental Ballistic Missile in 1957, gradually wore away at America's longstanding invulnerability to an external attack. He now could resort to atomic diplomacy in the attainment of his foreign policy aims, threatening to rain nuclear destruction on the West. It was this newfound assertiveness that propelled Moscow toward a series of crises in 1958-1962, most prominently, the Cuban Missile Crisis.

All the while, Nikita Khrushchev was looking for a personal relationship with an American President, something he finally managed to obtain in September 1959, during his widely publicized tour of the United States. Khrushchev and President Dwight D. Eisenhower inaugurated what came to be known as the Spirit of Camp David-relaxation of superpower tensions born of the realization by both of the destructive power of nuclear weapons. After his visit to the United States, Khrushchev flew to China, where he had the indiscretion to advise Mao to release a handful of American citizens that the PRC authorities held in captivity on espionage charges. He clashed with the Chinese on a range of other issues, in particular on India, which had just fought a serious of skirmishes with the Chinese over disputed territories in the Himalayas. Khrushchev proclaimed neutrality in the conflict, which the Chinese rightly deemed to have been a betrayal of allied obligations. In Mao's view, Khrushchev had ganged up with China's enemy to bully an ally. ${ }^{7}$

The theme of "bullying" (usually in "collusion") with the United States henceforth appeared with great regularity in China's foreign policy discourse. As Foreign Minister Chen Yi put it in 1962, "Now in the world big countries bully big countries, as in America bullying China (hint: India is also bullying us); big countries bully small countries, as in America bullying lots of small countries; small countries bully small countries, as in Thailand bullying Cambodia; there are also small countries

\footnotetext{
7 Conversation between Nikita Khrushchev and the Chinese leaders. October 2, 1959. Translated by David Wolff. https://digitalarchive.wilsoncenter.org/document/118883. Accessed 20 Dec 2019.
} 
bullying big countries... China is the most bullied country. It is bullied by big countries, and it is also bullied by small countries". ${ }^{8}$ Khrushchev-in part because of his rash temper and do-first-think-later propensities, was particularly liable to be singled out as a bully by the sensitive Chinese leaders. One example was his decision, in 1960, to withdraw Soviet experts from China, which was a form of sanctioning Beijing for increasingly confrontational behavior. There was further "bullying" in the Soviet-American arms control negotiations, leading in August 1963 to the signing of the Partial Nuclear Test Ban Treaty. The treaty, in Mao's opinion, was an attempt to sabotage the (by then rapidly advancing) Chinese nuclear program.

Even Khrushchev's ouster in October 1964 did not alleviate Mao's suspicions of Soviet intentions. The charge of "collusion" with the United States was renewed in connection with the war in Vietnam (Beijing accused the Soviets of colluding with the Americans to help them "find a way out of Vietnam".) Meanwhile, Soviet efforts to undertake joint action with China to help an ally-in-need were scoffed at as insincere. In February 1965, Mao Zedong famously told the new Soviet Prime Minister Aleksei Kosygin that the Sino-Soviet struggle would continue for 10,000 years. ${ }^{9}$ Relations continued to deteriorate, fuelled by the unfolding Cultural Revolution in China. Once Mao assigned his domestic enemies, the label of "revisionists" (hitherto reserved for the Soviets and the Yugoslavs), rebuilding ties with Moscow became even more difficult, since any gain for Sino-Soviet relations was a gain for Mao's perceived domestic enemies, most notably "China's Khrushchev" Liu Shaoqi.

The Soviets did not have the same kind of close linkage between their domestic policy and their relationship with China. Throughout the 1960s and, indeed, the 1970 s, they were more inclined than the other side to repair the fissures in the Sino-Soviet alliance. But they were only willing to do so on the basis of the strict hierarchy that had previously determined the structure of the relationship. The basic parameters of this hierarchy were spelled out by Nikita Khrushchev in 1963; they reveal the nature of the Soviet outlook on allied relationships. Asked what he thought about the source of Sino-Soviet disagreements, Khrushchev had the following to say: "[It's] a question of nationalism, a question of egotism. This is the main thing. They want to play the first fiddle". He added: "But this is not decided by vote. This is determined by one's status and by the others' recognition. Even among friends: 5-10 people are friends, and one of them is the leader. They don't elect him. They just recognize him for certain qualities. This is how it is, and how it will be in the future. People won't all be black or red-haired. There will be different colours, and different temperaments, and different mental capabilities among people. There will be inequality, like elsewhere in nature". (Fursenko 2015, 720).

What Khrushchev meant by these peculiar remarks was that the Soviet Union was naturally more capable of leading the socialist camp than China, and so it would

\footnotetext{
${ }^{8}$ Chen Yi's speech at the Political Consultative conference session. April 17, 1962. Gansu Provincial Archives, 116-2-1-350, pp. 37-38.

9 Minutes from a Conversation between A.N. Kosygin and Mao Zedong. February 11, 1965. History and Public Policy Program Digital Archive, AAN, KC PZPR, XI A/10, 517, 524. Obtained by Douglas Selvage and translated by Malgorzata Gnoinska. https://digitalarchive.wilsoncenter.org/document/11803 9. Accessed 20 Dec 2019.
} 
remain. Khrushchev's fall in October 1964 may have brought back a degree of nuance and the rediscovered willingness to consult with allies, but new Soviet leadership-including General Secretary Leonid Brezhnev-remained determined to stay in control. If China wanted back under the Soviet wing, it would have to defer to Moscow's authority. Mao would have none of that, which helps explain why, even as China in the early 1970s began to gradually improve relations with some of the Soviet allies (through the policy of differentiation), it remained adamantly at odds with the Soviets. As Mao put it to Romania's leader Nicolae Ceausescu in June 1971: "You [the Soviet Union] piss on my head and I should respect you? ... No matter who tries to persuade us [to mend fences], we won't move. The more they talk the worse relations will become". ${ }^{10}$

\section{The Sino-Soviet normalization}

In March 1969, China and the Soviet Union very nearly went to war over their disputed border. Fearful of a Soviet invasion, Mao probed for the possibility of a Sino-American rapprochement. This process led, in February 1972, to President Richard Nixon's visit to Beijing. By building bridges to China and (through the tortuous process of détente) to the Soviet Union, the Americans were presently in a better relationship with either than the two were with each other. President Nixon and his National Security Adviser Henry Kissinger skilfully played on the Sino-Soviet contradictions. It was not difficult to do, given the degree of distrust between the former allies. The Sino-Soviet border negotiations dragged on without making any visible progress. The Chinese accused Moscow of "suspending the atomic bomb over the negotiating table" (Kireev 2006, 126). For their part, the Soviet leaders conjured wild images of a Chinese cross-border invasion to capture the resource-rich but sparsely populated regions of the Soviet Far East. Leonid Brezhnev repeatedly tried to persuade Nixon of the long-term danger of the resurgent Chinese, whom he held to be-in a true Orientalist fashion- "treacherous and spiteful", "not honorable", and "exceptionally sly and perfidious". 11

Mao Zedong died in 1976, but the Sino-Soviet confrontation, which he had richly contributed to, continued unabated. This was partly a question of inertia. Anti-Chinese views became institutionalized in the Soviet Union, as the Sino-phobic hawks such as Boris Rakhmanin (deputy head of a Central Committee department responsible for relations with socialist countries) stubbornly clung to negative interpretations of China's evolving foreign policy. Leonid Brezhnev's physical decline (by the late 1970s, he was incapable of independent decision-making), gave the likes of Rakhmanin even more space to pursue a hostile policy toward China.

\footnotetext{
${ }^{10}$ Conversation between Mao Zedong and Nicolae Ceausescu, June 3, 1971.(In the author's personal collection).

11 Memorandum by the President's Assistant for National Security Affairs (Kissinger) for the President's File. June 23, 1973. In Selvage et al. (2008), pp. 534-538. https://history.state.gov/historicaldocuments/ frus1969-76v15/d131. Accessed 20 Dec 2019.
} 
On the Chinese side, Deng Xiaoping (who eventually inherited the reins of leadership from Mao) was also in no hurry to mend fences with Moscow. He was less preoccupied than Mao had been with the supposed Soviet betrayal of Marxism-Leninism (the term "revisionism" had by then long gone out of fashion) but remained just as concerned about the prospect of Soviet geopolitical gains in Asia. Deng developed a theory, whereby he likened the Soviet strategy to a weight barbell: on the one hand, there was Moscow's push toward Southeast Asia (through closer relations with Vietnam); on the other hand, the Soviets were expanding in the Middle East (where, in 1979, they invaded Afghanistan). Linking the two "weights" was the "bar"- the Malacca Straits. Deng brought up this "theory" on many occasions, not least with his American interlocutors, to highlight the continued danger of Soviet expansionism. The Chinese leader claimed that he was not, in principle, against improved relations; only, he wanted the Soviet Union to remove certain "obstacles"-withdraw forces from Afghanistan and the Sino-Soviet border (including Mongolia, which hosted an entire Soviet land army), and induce Vietnam to pull back from Cambodia, which China's former ally (now enemy) invaded in 1978.

Sino-Soviet relations began to improve visibly only in the early 1980s, when the Chinese leaders reciprocated tentative Soviet probes. Deng's willingness to unfreeze the relationship stemmed from two observations. First, the Soviet Union evidently proved a less formidable foe than at first feared. The Soviet misadventure in Afghanistan was running into serious difficulties; the Mujahedeen maintained an effective guerrilla resistance against the occupying force (of course, with the help of Pakistan, the United State, and China itself). It seemed like Moscow had overextended itself (in fact, this was one of the reasons Soviet leaders were feeling the ground for rapprochement with China). Second, Deng was disappointed with what he perceived as America's duplicity, in particular in connection with the continued sale of weapons to Taiwan. Given how apprehensive the American policymakers remained of the prospects of the Sino-Soviet normalization, moving toward such normalization seemed like something that could benefit both Moscow and Beijing. In short, the Sino-Soviet normalization was a consequence of a realization by both the Chinese and the Soviet leaders that they would each be in a better position to deal with the United States if they were not also bitterly opposed to one another.

The most important condition of normalization was the change in the structure of the Sino-Soviet relationship. Mikhail Gorbachev, who in March 1985 took the helm in the Soviet Union, did not cling to the outdated hierarchy that proved so unacceptable to Mao. What this meant became clear in December 1985, during a meeting between Gorbachev and then-Chinese deputy Prime Minister Li Peng. "China will not become [the Soviet Union's] younger brother", Li Peng told the Soviet leader. Gorbachev recounted his response: "I said it would just be difficult to imagine China in the role of a younger brother" (Radchenko 2014, 160). But that had never been difficult to imagine for Stalin, Khrushchev or Brezhnev- that was the big difference.

The process of normalization edged forward gradually. Gorbachev was not in a rush to remove Deng's "three obstacles". Deng eventually relented. Indeed, the only obstacle that was fully removed before normalization was Afghanistan (the last Soviet troops left the country in February 1989). In May, Deng Xiaoping welcomed Gorbachev to Beijing to "close the past and open the future". During their 
conversation, Deng explained his take on the difficulty history of the Sino-Soviet relationship. "The Soviet Union", he argued, "incorrectly perceived China's place in the world... The essence of all problems was that we were unequal, that we were subjected to coercion and pressure" (Radchenko 2014, 167).

\section{Conclusion}

The Soviet collapse did not arrest the positive dynamic in what became the Sino-Russian relationship. This was even despite the fact that Russia's first President Boris Yeltsin initially pursued a pro-Western foreign policy. Yeltsin, like Gorbachev before him, understood that a positive relationship with China was a tremendous foreign policy asset regardless of the state of Russia's relations with the West. Once the initial post-Cold War euphoria wore off, and Moscow found itself at odds with the West on a growing number of international issues (not least Yugoslavia and the prospects of NATO enlargement), maintaining a problem-free dialogue with Beijing acquired new importance. Yeltsin developed a fairly close partnership with General Secretary Jiang Zemin, and the two presided over the inauguration of what later became the comprehensive strategic partnership between China and Russia.

The new relationship lacks an important element that characterized the old Sino-Soviet alliance - the ideological aspect. Yet ideology or, to be more specific, the right to interpret ideology, was one of the most contentious issues of Sino-Soviet relations. Ideology did not derail the alliance-it fell apart largely for other reasons-but it helped rationalize the downward slide in the relationship and made it more difficult for the two sides to mend fences, because doing so required one side to defer to the other's leadership, and this leadership was inevitably defined in ideological terms. Ridding the Sino-Russian relationship of ideology actually immeasurably strengthened it. But although the Marxist-Leninist backdrop to the bilateral relationship has fallen away, certain ideational aspects remain in place. Just as during the Cold War, both sides continue to see the United States as their significant other, and both value the relationship with the US more highly than they value their bilateral relationship. Although both are opposed to the American-led world order, by their opposition to it, they implicitly acknowledge its existence, and their subordinate places in a global pecking order dominated by United States.

This is not to say that China and Russia are merely in a "marriage of convenience". One of the lessons of the Cold War is that there is in fact an internal dynamic to this relationship that must be looked after regardless of what happens or fails to happen in Washington. The two countries' elites have come to appreciate the other side as important partners in their own right, and there is determination in Beijing and Moscow not to allow the repeat of the drama of the Sino-Soviet split. Are there dangers that history may repeat itself?

This is unlikely. The fundamental problem of the Sino-Soviet alliance was precisely that it was an alliance, and one extremely rigid and hierarchically structured at that. The Sino-Russian relationship today is not an alliance. It could perhaps be 
described as a quasi-alliance, but the "quasi" prefix provides considerable flexibility, and the two countries are free to agree to disagree, something that was certainly lacking in the 1950s, when any disagreement was perceived as China's challenge to the Soviet authority. The tables have now been turned on Russia; between the two of them, it is certainly the junior partner. It seems, however, that this junior role is one that Russia has largely reconciled itself to. In the 1950s, Mao privately harbored hopes of China's rapid emergence as a superpower; today, Putin cannot possibly entertain such hopes, which lessens the danger of a potential struggle for leadership between the two countries.

There is, however, plenty of scope for Sino-Russian conflict in Central Asia and other regional theaters, and here Beijing must act with care and circumspection. After all, the difference between a friend and an enemy is merely that of perception, and-as the history of Sino-Russian relations testifies only too well-perceptions have the uncanny quality of shifting over time.

Open Access This article is licensed under a Creative Commons Attribution 4.0 International License, which permits use, sharing, adaptation, distribution and reproduction in any medium or format, as long as you give appropriate credit to the original author(s) and the source, provide a link to the Creative Commons licence, and indicate if changes were made. The images or other third party material in this article are included in the article's Creative Commons licence, unless indicated otherwise in a credit line to the material. If material is not included in the article's Creative Commons licence and your intended use is not permitted by statutory regulation or exceeds the permitted use, you will need to obtain permission directly from the copyright holder. To view a copy of this licence, visit http://creativecommons.org/licen ses/by/4.0/.

\section{Reference}

Chen, Jian. 2010. Mao's China and the Cold War. Chapel Hill, NC: University of North Carolina Press. Fursenko, A.A. (ed.). 2015. Prezidium TsK Kpss 1954-1964, vol. 1. Moscow: Rosspen.

Hajimu, M. 2015. Cold War crucible: the Korean conflict and the postwar world. Cambridge, MA: Harvard University Press.

Heinzig, D. 2015. The Soviet Union and Communist China 1945-1950: The Arduous Road to the Alliance: The Arduous Road to the Alliance. New York, NY: Routledge.

Hershberg, J, and Jian Chen. 2006. Informing the enemy: Sino-American 'Signalling' and the Vietnam War, 1965. In Behind the Bamboo Curtain: China, Vietnam, and the World beyond Asia. ed. Priscilla Roberts, 193-258. Washington D.C. and Stanford: Woodrow Wilson Center Press and Stanford University Press.

Literature Research Centre, C.P.C. (ed.). 1989. Jianguo Yilai Mao Zedong Wengao(建国以来毛泽东文 稿), vol. 1. Beijing: Central Party Literature Press.

Kireev, G.V. 2006. Rossiya-Kitai: Neizvestnye Stranitsy Pogranichnykh Peregovorov. Moscow: Rosspen.

Ledovskii, A., et al. 2005. Sovetsko-Kitaiskie Otnosheniia, vol. 5, book 2, 1946-February 1950, trans. Sergey Radchenko. Moscow: Pamiatniki Istoricheskoi Mysli.

Lüthi, L.M. 2008. The Sino-Soviet split: Cold War in the communist world. Princeton, NJ: Princeton University Press.

Mao, Zedong. 1998. Selected works of Mao Zedong on diplomacy. Beijing: Foreign Languages Press.

Radchenko, S. 2014. Unwanted Visionaries: The Soviet Failure in Asia at the End of the Cold War. New York, NY: Oxford University Press.

Selvage, D.E., et al. (eds.). 2008. Foreign Relations of the United States, 1969-1976, Volume XV, Soviet Union, June 1972-August 1974. Washington, DC: Bureau of Public Affairs, Office of the Historian. 
Shen, Zhihua, and Yafeng Xia. 2015. Mao and the Sino-Soviet Partnership, 1945-1959: A New History. Lanham: Lexington Books.

Wendt, A. 1992. Anarchy is what states make of it: the social construction of power politics. International Organization 46 (2): 391-425.

Wu, Lengxi. [吴冷西]. 1999. Shi Nian Lun Zhan:1956-1966 Zhong Su Guanxi Huiyilu (十年论战:19561966中苏关系回忆录). Beijing: Central Party Literature Press. 